International Journal of Engineering \& Technology, $7(3.35)(2018) 43-51$
International Journal of Engineering \& Technology
SPC
Website www.sciencepubco.com/index.php/IJET
Research paper

\title{
Effect of Mineral Admixtures on Mechanical Properties of Concrete with Partially Replacement of Flyash and Ggbs
}

\author{
Pothunuri shalini kumari' ${ }^{1}$ Kuppala Srinivasa Rao $^{2}$ and Tirumala Deepika ${ }^{3}$ \\ ${ }^{1}$ Assistant professor, Vidya Jyothi Institute of Engineering and Technology, Hyderabad. Telangana. Email: shalinipothunuri@gmail.com \\ ${ }^{2}$ Assistant professor, Sir C R Reddy College of Engineering, Eluru, Andhra Pradesh. \\ Email: ksrao.ce@gmail.com \\ ${ }^{3}$ Assistant professor,Vidya Jyothi Institute of Engineering and Technology, Hyderabad. Telangana. \\ Email:tirumaladeepika733@gmail.com
}

\begin{abstract}
Being humans the usage of concrete is more and more important now a days. Generally many people have dreams to construct their own houses and also government is take up many big projects like construction of dams, bridges etc. This shows us the necessity of production of huge amount of concrete. But for the production of concrete tremendous amount of cement is required, which in turn leads to the release of large amounts of $\mathrm{CO}_{2}$ into the atmosphere during its manufacturing process. It causes adverse effects to the environment. To decrease amount of $\mathrm{CO}_{2}$ and its adverse effects, we partially replaced the cement with mineral admixtures like GGBS and Fly ash. The present study dealt with the mechanical properties of concrete by using various percentages of mineral admixtures with water to binder content ratio 0.4 and M40 grade of concrete.
\end{abstract}

Keyword: GGBS, Fly ash, Mechanical Properties, Binder, Mineral Admixture and Concrete.

\section{Introduction}

Concrete is the most widely used construction material. Concrete is a blend of unalterable material, fine aggregate, coarse aggregate and water in suitable proportion. Cement concrete is expressed in the form of ratio of ingredients. This ratio represents the quantity of cement, fine aggregate and coarse aggregate. In addition to these three ingredients water is essential. Without water chemical reaction of cement is not possible. This chemical reaction will impart strength and hardness to the mix. The water causes the hardening of concrete through a process called hydration. Hydration is a chemical reaction in which the major compounds in cement form chemical bonds with water molecules and become hydrates or hydration products.

Ingredients of Cement Concrete:

Cement

Aggregate

Fine aggregate

Coarse aggregate

Water

\subsection{CEMENT:}

Cement is obtained by pulverizing clinker formed at $15000 \mathrm{c}$ by calcining raw material primarily consisting of lime (Cao), silicate (sio2), alumina (A12o3) and iron oxide ( $\mathrm{Fe} 2 \mathrm{o} 3)$. This is obtained by crushing of clinkers, formed by burning of well-proportioned calcareous and argillaceous materials at high temperatures.
Cement acts as a good binding material. It sets quickly and contributes sufficient strength to all structures.

\subsection{AGGREGATES:}

Sand is a natural building material.Sand should pass through 4.75 mm IS sieve and contains not more than $5 \%$ of coarse material. The main purpose of using sand in preparation of concrete is to fill the voids between coarse aggregates to form good bond. Generally river sand and robo sand are used specific gravity of F.A range is 2.4 to 2.6 .

\subsubsection{COARSE AGGREGATES:}

Crushed stone or gravel retained on IS $4.75 \mathrm{mmsieve}$ is used in preparation of concrete. Generally $20 \mathrm{~mm}$ and $10 \mathrm{~mm}$ size aggregates are used in concrete. Coarse aggregate is from stone crushing machines. It should be free from dust if any dust is found on the surface of aggregate it should be cleaned and washed with water before use specific gravity of C.A range is 2.6 to 2.8 .

\subsection{WATER}

It is the most important ingredient of concrete it takes part in chemical reaction with cement and gives strength and durability to concrete. Water should be free from salts, and certain injurious chemicals. The quantity water should be just sufficient for chemical reaction and suitable for workability of the concrete. 


\subsection{FLY ASH:}

Fly ash is a secondary product of the combustion of pulverized coal in thermal plants. The addition of fly ash in the concrete mix reduces the water content required to produce a certain level ofWorkability. The addition of fly ash has effects on many properties such as workability, hydration, strength development shrinkage, heat evolution and durability.Fly ash is used as a supplementary cementitious material (SCM) in the production of Portland cement concrete.

Table1 Properties of Fly Ash

\begin{tabular}{|c|c|}
\hline Parameters & Fly Ash \\
\hline Bulk Density (gm./cc) & $0.9-1.3$ \\
\hline Specific Gravity & $1.6-2.6$ \\
\hline Plasticity & Lower or non-plastic \\
\hline Shrinkage Limit (Vol Stability) & Major fine sand / silt and small \\
per \\
Grain size & cent of clay size particles \\
\hline Clay (percent) & Negligible \\
\hline Free Swell Index & Very low \\
\hline Classification (Texture) & Sandy silt to silty loam \\
\hline Water holding capacity percentage & $30-60$ \\
\hline Porosity (per cent) & $50-65$ \\
\hline Surface Area (m2 / kg) & $1-8$ \\
\hline Lime reactivity (MPa) & \\
\hline
\end{tabular}

\subsection{GGBS (Ground Granulated Blast slag):}

It is a byproduct of iron manufacturing industry .Its production requires less energy as compared to the production of the Portland cement. The carbon dioxide gas emission reduction will be happen by using Portland cement.

One of the accepted methods is through the use of GGBS concrete containing $50 \%$ to $90 \%$ GGBS. Generally, a combination of $70 \%$ GGBS and 30\% OPC is recommended. Resistance to chemical attack may be enhanced by using GGBS in concrete. Resistance to acid attack may be improved through the use of $70 \%$ GGBS. To counter the problem of sulphate and chloride attack $40 \%$ to $70 \%$ GGBS may be used.

\subsection{CONPLAST SP 430:}

Conplast SP430 is a chloride free, superplasticising admixture based on selected sulphonated naphthalene polymers. It is supplied as a brown solution which instantly disperses in water. Properties of Conplast SP430: High Range water reducing Superplasticizing Admixture.

\subsection{Properties of Conplast SP430}

High range water reducing/Superplasticizing admixture Water Reduction $>12 \%$ compared with Reference mix Increase of consistence Increase $>120 \mathrm{~mm}$ from initial slump Initial flow Retention of Consistence At 30 minutes> Reference mix at initial flow

Compressive strength is fulfilled.

Specific gravity: Typically 1.20 at $20^{\circ} \mathrm{C}$

Chloride content: Nil to BS 5075

Air entrainment : Typically less than $2 \%$ additional air is entrained at the normal dosage.

\section{Literature Review}

S. Arivalagan 1 et al. The present paper is an effort to quantify the strength of ground granulated blast furnace slag (GGBS) at various replacement levels and evaluate its efficiencies in concrete. This research evaluates the strength and strength efficiency factors of hardened concrete, by partially replacing cement by various percentages of GGBS for M35 grade of concrete at different ages. From this study, it can be concluded that, since the grain size of GGBS is less than that of ordinary Portland cement, its strength at early ages is low, but it continues to gain strength over a long period and the degree of workability of concrete was normal with the addition of GGBS up to $40 \%$ replacement level for M35 grade concrete.

Himabindu Myadaraboina2 et al. the use of high volume fly ash as cement replacement can of superplasticizer needed in comparison to normal cement concrete.

T.Renganathan3et al. The replacement of $50 \%$ of GGBS due to low heat of hydration, the compressive strength increases gradually as the curing day increases. Along with GGBS, flyash is also blended with cement to make the triple blend mix so as to surpass the compressive strength of OPC.

Shankar Mishra4et al. They have studied mechanical properties by replacing the cement with fly ash and GGBS. In the compressive strength of the mix i.e. $0 \%, 5 \%, 10 \%, 15 \%$ of GGBS with constant $15 \%$ FLY-ASH, the value increases $38 \mathrm{~N} / \mathrm{mm}$. It is also noted that the flexural strength increases gradually with increase in composition of GGBS and reaches up to $4.1 \mathrm{~N} / \mathrm{mm}$.

R.B.Sheral5et al. The compressive strength of conventional concrete and Geo-polymer concrete at $3,7 \& 28$ days shows similar behaviour for partial replacement and full replacement of cement with GGBS \& Fly ash. Cost analysis is carried out to know economy of present work and it is observed that cost required for conventional concrete, geo-polymer concrete (fly ash $60 \%$ and GGBS $40 \%$ ) \& (fly ash $30 \%$, GGBS 30\% \& cement $40 \%$ ) is nearly same.

P. Vipul Naidu6 et al. As the combination of lime and fly ash increases the strength, so we can replace the cement about $75 \%$ to that of cementitious material. Replacing cement by fly ash + lime up to $75 \%$ gives about $40.78 \%$ cost beneficial to that of original mix cost. Hence it is more economical because only $25 \%$ of cement is used to get M40 grade cement.

\section{Experimental Investigation}

\subsection{Tests on Cement}

\subsubsection{Fineness of Cement:}

Fineness of cement is measured by sieving it on standard sieve. The main objective is the fineness of cement has a great effect on rate of hydration and also fine's cement offer's a great surface area. Coarse cement particles settling down in concrete which causes bleeding. Excessive fineness requirement increases the cost of grinding and also use more water for hydration resulting reduced strength and durability. The fineness of cement test is done according to IS: $269-1989$ \& IS: 4031-1988

Table2 Observation Table of Fineness of Cement

\begin{tabular}{|l|l|l|l|}
\hline S.no & $\begin{array}{l}\text { Weight of sample } \\
\text { taken }(\mathbf{g m})\end{array}$ & $\begin{array}{l}\text { Weight of } \\
\text { residue } \\
\text { (gm) }\end{array}$ & \% Fineness \\
\hline 1 & 100 & 5 & 95 \\
\hline 2 & 100 & 5 & 95 \\
\hline 3 & 100 & 6 & 96 \\
\hline
\end{tabular}

Average fineness of cement $=5.33 \%$

Therefore, Fineness of cement $=94.67 \%$.

\subsubsection{NORMAL CONSISTENCY OF CEMENT:}

The normal consistency of cement test is that consistency at which the vicat plunger penetrates to a point of $5-7 \mathrm{~mm}$ from the bottom of vicat's mould. The standard consistency test of a cement is done by according to IS: $269-1989$ \& IS: $4031-1988$, Part -4 . 
Table3: Observation Table for Consistency of Cement

\begin{tabular}{|c|c|c|c|c|c|c|}
\hline \multirow[b]{2}{*}{ S.no } & \multirow{2}{*}{$\begin{array}{l}\text { Weight of cement } \\
\text { takizn in gn(a) }\end{array}$} & \multirow{2}{*}{$\begin{array}{l}\text { Q/wof water } \\
\text { added }\end{array}$} & \multirow{2}{*}{$\begin{array}{l}\text { Weight of w ater } \\
\text { taken in } \mathrm{ml}(\mathrm{b})\end{array}$} & \multicolumn{2}{|c|}{ Virat'sReading } & \multirow{2}{*}{$\begin{array}{l}\text { Plunger penetration } \\
\text { (mm) }\end{array}$} \\
\hline & & & & $\begin{array}{l}\text { Iritial } \\
(\mathrm{mm})\end{array}$ & $\begin{array}{l}\text { Fival } \\
(\mathrm{mm})\end{array}$ & \\
\hline 1 & 300 & 27 & 81 & 40 & 33 & 7 \\
\hline 2 & 300 & 29 & 87 & 40 & 25 & 15 \\
\hline 3 & 300 & 30 & 93 & 40 & 19 & 21 \\
\hline 4 & 300 & 31 & 93 & 40 & 12 & 28 \\
\hline 5 & 300 & 32 & 96 & 40 & 6 & 34 \\
\hline
\end{tabular}

Therefore, Normal consistency of cement is $32 \%$.

\subsubsection{Initial and Final Setting of Cement}

Initial and final setting time of cement is used to measure the rate of hardening of cement paste.

Initial \& Final Setting Times of Cement is done according to IS: 269- 1989 \& IS: 4031-1988, Part - 5 .

Therefore, Initial setting time for the given sample of cement $=35$ $\mathrm{min}$. Final setting time for the given sample of cement $=540 \mathrm{~min}$.

\subsubsection{Specific Gravity of Cement}

Specific gravity is normally defined as the ratio between the weight of given volume of material and weight of equal volume of water. The specific gravity of cement is 3.15 as per IS: 4031- Part 11- 1988

\subsubsection{Compressive Strength of Cement}

The strength of cement cubes is determined by compressive strength of cement mortars is IS: 269-1989(33G) IS: 81121989(43G), IS: 12269-1987(53G), IS: 4031-1988, Part - 4 \& IS: 4031-1988

\section{Formula:}

Compressive strength in $\mathrm{N} / \mathrm{mm}^{2}=\frac{P}{A}$

Where, $\mathrm{P}$ is the crushing load in $\mathrm{N}$ and $\mathrm{A}$ is the area in $\mathrm{mm}^{2}\left(4984.36 \mathrm{~mm}^{2}\right)$

\subsection{Tests on Fine Aggregates}

\subsubsection{Fineness Modulus of Fine Aggregate:}

Fineness modulus is a measure to define the fineness of aggregate to be used for the concrete. Because fineness increases, the void ratio also increase and strength of the concrete decreases. The fineness modulus test of fine aggregate is done according to relevant IS code.

Table4: Observation Table of Fineness Modulus of Sand

\begin{tabular}{|c|c|c|c|c|c|}
\hline S.no & $\begin{array}{l}\text { Sieve } \\
\text { size } \\
\text { mm } \\
\end{array}$ & $\begin{array}{l}\text { Weight } \\
\text { retainer }\end{array}$ & $\begin{array}{l}\text { \% Weight } \\
\text { retained }\end{array}$ & $\begin{array}{l}\text { \% Weight } \\
\text { passing }\end{array}$ & $\begin{array}{l}\text { Cumulative } \\
\% \text { Weight } \\
\text { retained }\end{array}$ \\
\hline 1 & 4.75 & 5 & 0.5 & 99.5 & 0.5 \\
\hline 2 & 2.36 & 38 & 3.8 & 96.2 & 4.3 \\
\hline 3 & 1.18 & 71 & 7.1 & 92.9 & 11.4 \\
\hline 4 & 0.60 & 240 & 24.0 & 76 & 35.4 \\
\hline 5 & 0.3 & 354 & 35.4 & 64.6 & 70.8 \\
\hline 6 & 0.15 & 252 & 25.2 & 74.8 & 96 \\
\hline 7 & Pan & 40 & 4.0 & 96 & 100 \\
\hline
\end{tabular}

Therefore, Fineness Modulus of sand $=3.184$

Fineness modulus of given sand type is Zone-3.

\subsubsection{Specific Gravity of Fine Aggregate}

The Specific gravity of fine aggregate is determined to known the water absorption capacity of the fine aggregate. The specific gravity test of fine aggregate is done according to IS: $2386-1963$, Part -3 .

Specific gravity of sand $=2.40$

\subsubsection{Bulking of Sand:}

Bulking of sand experiment is used to study the behaviour of sand grains under varying percentages of moisture content. The bulking of sand gives exact amount of sand is used for the preparation of concrete mix when water is absorbed by the sand. Bulking of sand is done according to relevant IS code. Therefore, the maximum bulking of the sand is $48 \mathrm{ml}$ at $6 \%$ moisture content.

\subsection{Tests on Coarse Aggregate}

\subsubsection{Fineness Modulus of Coarse Aggregate}

Fineness modulus of coarse aggregate test is used to define the size of aggregate used for the concrete. Larger size particles are not used due to increase of void ratio.

To determine the fineness modulus of coarse aggregate by IS test sieves, square hole perforated plate $80 \mathrm{~mm}, 40 \mathrm{~mm}, 20 \mathrm{~mm}, 10 \mathrm{~mm}$. The fineness modulus test of coarse aggregate is done according to relevant IS code.

Weight of coarse aggregate $=5000 \mathrm{gm}$

Table 5: Observation Table of Fineness Modulus of Coarse Aggregate

\begin{tabular}{|c|c|c|c|c|c|}
\hline S.No & $\begin{array}{l}\text { Sieve } \\
\text { size } \\
\text { Mm }\end{array}$ & $\begin{array}{l}\text { Weight } \\
\text { retained }\end{array}$ & $\begin{array}{l}\text { \%Weight } \\
\text { retained }\end{array}$ & $\begin{array}{l}\text { \%Weight } \\
\text { passing }\end{array}$ & $\begin{array}{l}\text { Cumulative } \\
\text { \% Weight } \\
\text { retained }\end{array}$ \\
\hline 1 & 80 & 0 & 0 & 100 & 0 \\
\hline 2 & 40 & 0 & 0 & 100 & 0 \\
\hline 3 & 20 & 2024 & 40.48 & 59.52 & 40.48 \\
\hline 4 & 10 & 2903 & 58.06 & 1.46 & 98.54 \\
\hline 5 & 4.75 & 8 & 1.36 & 0.10 & 100 \\
\hline 6 & 2.36 & - & - & - & 100 \\
\hline 7 & 1.18 & - & - & - & 100 \\
\hline 8 & 0.6 & - & - & - & 100 \\
\hline 9 & 0.3 & - & - & - & 100 \\
\hline 10 & 0.15 & - & - & - & \\
\hline \multicolumn{5}{|c|}{ retained } & 738.92 \\
\hline
\end{tabular}

Therefore, Fineness Modulus of Coarse aggregate $=7.38$

\subsubsection{SPECIFIC GRAVITY OF COARSE AGGREGATE}

The Specific gravity of coarse aggregate is determined to known the water absorption capacity of the coarse aggregate. The specific gravity of coarse aggregate is done according to IS: $2386-1963$, Part -3,

Specific gravity of coarse aggregate $=2.78$

\subsection{Workability}

A theoretical water/cement ratio calculated from the considerations discussed above is not going to give an ideal situation for maximum strength. Hundred per cent compaction of concrete is an important parameter for contributing to the maximum strength. Lack of compaction will result in air voids whose damaging effect on strength and durability is equally or more predominant than the presence of capillary cavities.

Workability as "the property of concrete which determines the amount of useful internal work necessary to produce full compaction."Some of the tests, measure the parameters very close to workability and provide useful information. The following tests are commonly employed to measure workability.

Workability Tests :

- $\quad$ Slump cone test 
- Compaction factor test

- Vee-Bee consistometer test

\subsubsection{Slump cone test : ( IS 7320:1974)}

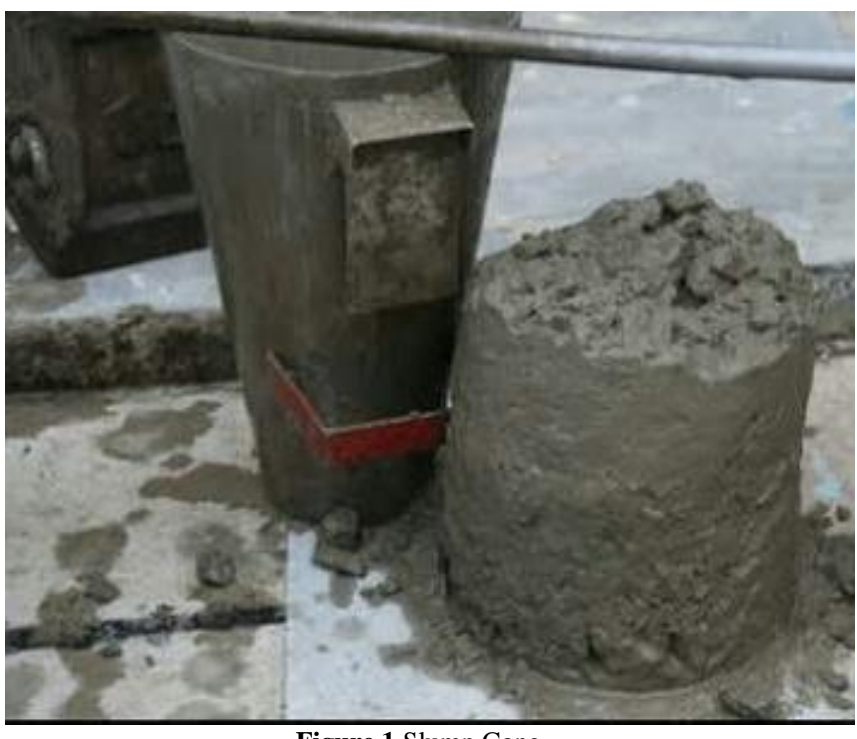

Figure.1 Slump Cone

To find the consistency of concrete slump test is done by using slump cone which can be employed either in laboratory or at site of work. It is not a suitable method for very wet or very dry concrete.

The appartus for conducting the slump test essentially consists of a metallic mould in the form of a frustum of a cone having the internal dimensions as under:

- Bottom diameter : $20 \mathrm{~cm}$

- Top diameter : $10 \mathrm{~cm}$

- Height : $30 \mathrm{~cm}$

The pattern of slump is divided into three types. It indicates the characteristic of concrete in addition to the slump value. If the concrete slumps evenly it is called true slamp. If one half of the cone slides down, it is called shear slump. In case of a shear slump, the slump value is measured as the difference in height between the height of the mould and the average value of the subsidence. Shear slump also indicates that the concrete is noncohesive and shows the characteristic of segregation.

\section{Test Procedure:}

1. Weigh the constituents of concrete dry state. First mix cement and sand thoroughly and then coarse aggregate and again mix thoroughly to get a uniform color. Make a dip at the center of the heap and pour some part of already weighted water (i.e., by w/c ratio). mix concrete but slowly adding the remaining quantity of water.

2. Clean the internal surface of the mould (cone) and place it over a smooth, horizontal and nonabsorbent surface (eg metal plate). Firmly held in position and fill it with fresh concrete in four equal layers.

3. Tamp each layer of concrete with the tamping rod for 25 times, distributing the blows in a uniform manner over the cross section of mould. For the second and subsequent layers the tamping rod should penetrate. Into the preceding layer.

4. Using the tamping rod or a trowel strike off the excess concrete above the top of the cone. Measure the vertical Calculations height of cone,(h1).

Height of concrete cone before slump, $\mathrm{h}_{1}=30 \mathrm{~cm}$ Height of concrete cone after slump, $\mathrm{h}_{2}=19 \mathrm{~cm}$ Therefore slump $\left(\mathrm{h}_{1}-\mathrm{h}_{2}\right)=11 \mathrm{~cm}$

\section{Compaction Factor Test:}

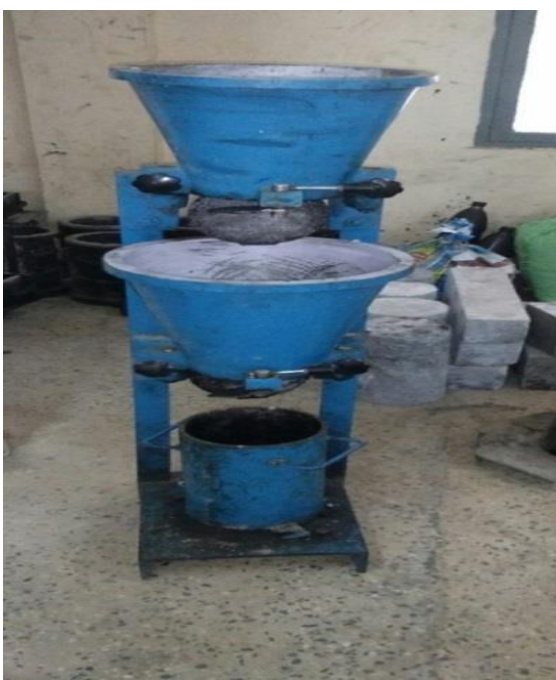

Figure 2 Compaction factor test on concrete

The compacting factor test has been developed at the Road Research Laboratory U.K. and it is claimed that it is one of the most efficient tests for measuring the workability of concrete. This test works on the principle of determining the degree of compaction achieved by a standard amount of work done by allowing the concrete to fall through a standard height. The degree of compaction, called the compacting factor is measured by the density ratio i.e., the ratio of the density actually achieved in the test to density of same concrete fully compacted.

\section{Test Procedure:}

1. Apply grease to the inner surface of the hoppers (buckets) and cylinder.

2. Fasten (close) the hopper doors.

3. Weight the empty cylinder, (w1). Fix the cylinder at the center of hoppers,(i.e., insert in the appropriate holes).

4. Fill the upper hopper with freshly mixed concrete, without any compaction. After 2 minutes, release the trap door, allowing the concrete to fall into the lower hopper and bringing the concrete into a standard compaction.

5. As soon as the concrete comes to rest release the trap door of the lower hopper and allow the concrete to fall into the cylinder. Remove excess concrete, above the top surface of cylinder with a trowel, without any compaction. Clean the sides of the cylinder and note the weight of cylinder with partially compacted concrete,(w2).

6. Empty the cylinder and refill it with the same sample of concrete in $5 \mathrm{~cm}$ layer heavily compacting each layer (preferably by vibration), to obtain full compaction of concrete, strike off the excess concrete and weigh the cylinder with fully compacted concrete,(W3).

7. The ratio of the compacted concrete. W1)/(W3-W1), Gives the compaction factor.

\section{Calculations:}

1. Weight of empty cylinder, $\mathrm{W}_{1}=7.5 \mathrm{~kg}$

2. Weight of cylinder with partially compacted concrete, $\mathrm{W}_{2}=17 \mathrm{~kg}$

3. Weight of cylinder with fully compacted concrete, $\mathrm{W}_{3}=18.9 \mathrm{~kg}$

Compaction factor test $=0.83$

\section{Vee Bee Consistometer:}

This is a good laboratory test to measure indirectly the workability of concrete. This test consists of a vibrating table, a metal pot, a 
sheet metal cone, a standard iron rod. Slump test as described earlier is performed, placing the slump cone inside the sheet metal cylindrical pot of the consistometer. The glass disc attached to the swivel arm is turned and placed on the top of the concrete in the pot.

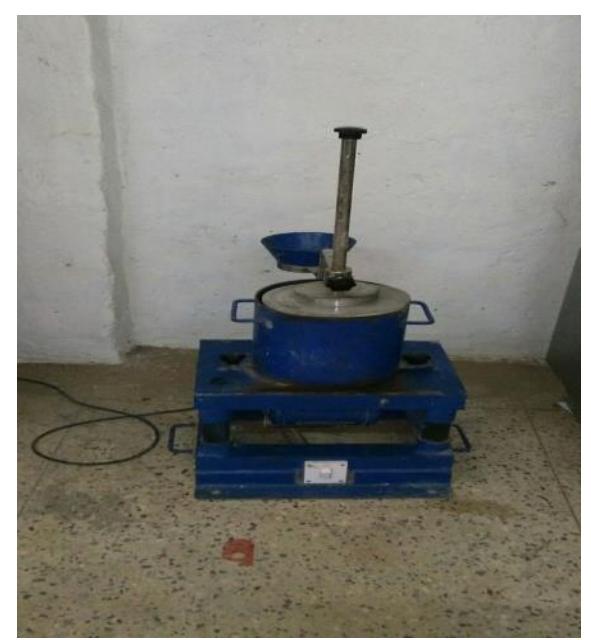

Figure 3 Vee Bee Consistometer

The electrical vibrator is then switched on and simultaneously a stop watch started. The vibration is continued till such a time as the conical shape of the concrete disappears and the concrete assumes a cylindrical shape. This can be judged by observing the glass disc from the top for disappearance of transparency. Immediately when the concrete fully assumes a cylindrical shape, the stop watch is switched off. The time required for the shape of concrete to change from slump cone shape to cylindrical shape in seconds is known as Vee Bee Degree.

\section{Test Procedure:}

1. Clean the internal surface of the mould (cone) and place it inside the sheet met cylindrical part of the consistometer. Firmly held the cone in position and fill it with fresh concrete in four equal layer.

2. Tamp each layer of concrete rod for 25 times, distributing the blow in a uniform manner over the cross-section of mould. For the second and subsequent layers the tamping rod should penetrate in to the preceding layer.

3. Using a tamping rod or trowel strike off the excess above the top of the cone. Attach the glass disc to the swivel arm. Place the glass plate over the slump cone and note the position of a concrete cone by adjusting the glass disc.

4. Turn the swivel, slowly and carefully remove the cone in vertical direction soon as the cone is removed, turn the swivel arm and place the glass plate over concrete cone.

5. Switch on the electric vibrator of the vee-bee consist meter. Simultaneously the stop watch. Continue the vibration, until the whole concrete surface, uniformly adheres to the glass disc. At this stage, stop the stop watch and note the lapse time in second.

6. Express the consistency of concrete in VB-time which is equal to the lapse time second.

CAlCUlations: VB- Time $=19$ Seconds.

\section{Experimental Results}

\subsection{Compressive Strength:}

To find the strength of hardened concrete the most common test is compressive test.This test is easy to conduct most of the advantageous characteristics properties of concrete are related to its strength.

Compressive Strength $=\frac{\text { Max } \text { Load }}{\text { Area }}=\frac{P}{A}$

Where,

$\mathrm{P}=$ Maximum Load on Cube in $\mathrm{KN}$

$\mathrm{A}=$ Effected cross sectional area in $\mathrm{mm}^{2}$

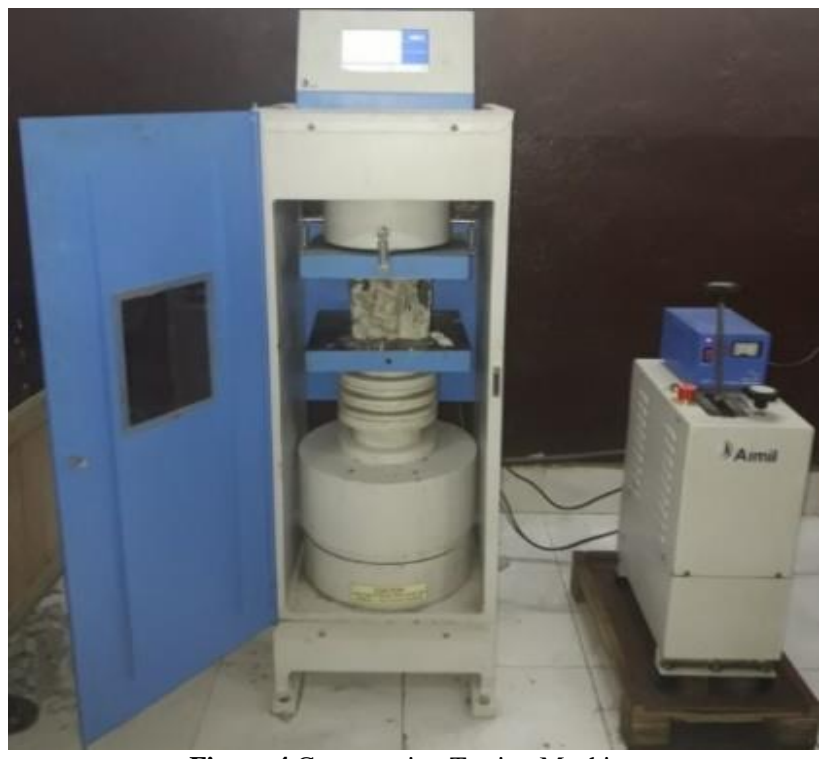

Figure 4 Compression Testing Machine

The compression test is carried on specimens cubical or cylindrical in shape. The cube specimen is of the size $15 \times 15 \times 15$ $\mathrm{cm}$. The cylindrical test specimens have a length equal to the twice of the diameter. They are $15 \mathrm{~cm}$ in diameter and $30 \mathrm{~cm}$ long.

Table 6 Compression Strength Test Results

\begin{tabular}{|c|c|c|c|}
\hline \multirow{2}{*}{ Percentage \% } & \multicolumn{3}{|c|}{ Compression Strength $\left(\mathbf{N} / \mathbf{M m}^{2}\right)$} \\
\cline { 2 - 4 } & 7 Days & 28 Days & $\mathbf{5 0 ~ D a y s}$ \\
\hline 0 & 26 & 35.2 & 43 \\
\hline 10 & 23.7 & 33.2 & 42 \\
\hline 15 & 22.1 & 34.21 & 43.1 \\
\hline 20 & 20.3 & 38 & 44.8 \\
\hline 25 & 20.2 & 26 & 36.2 \\
\hline 30 & 17.25 & 23.35 & 29.74 \\
\hline 40 & 14.8 & 28.55 & 29.12 \\
\hline
\end{tabular}

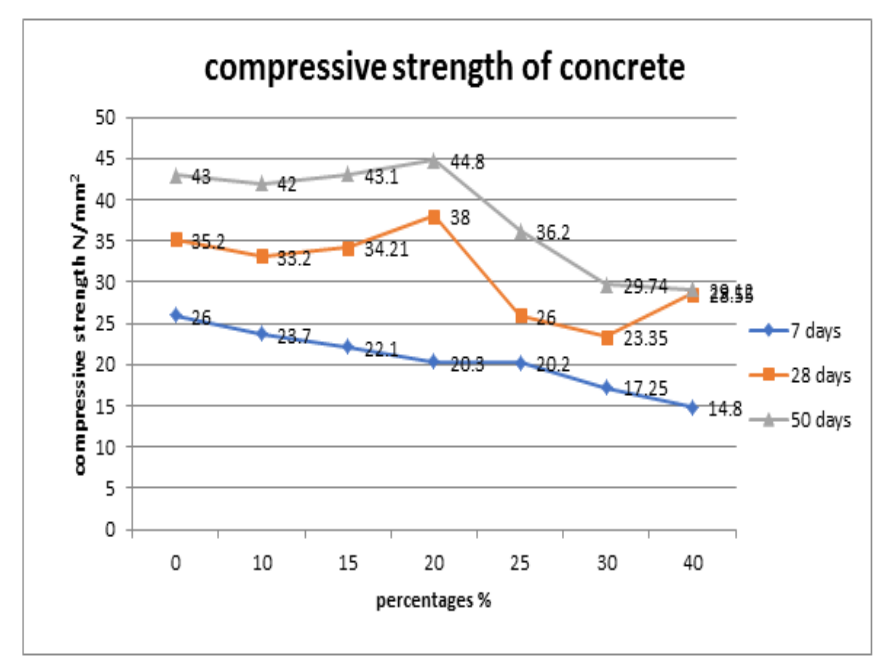

Figure 5: Compressive Strength of Concrete for various percentages of mineral admixtures 


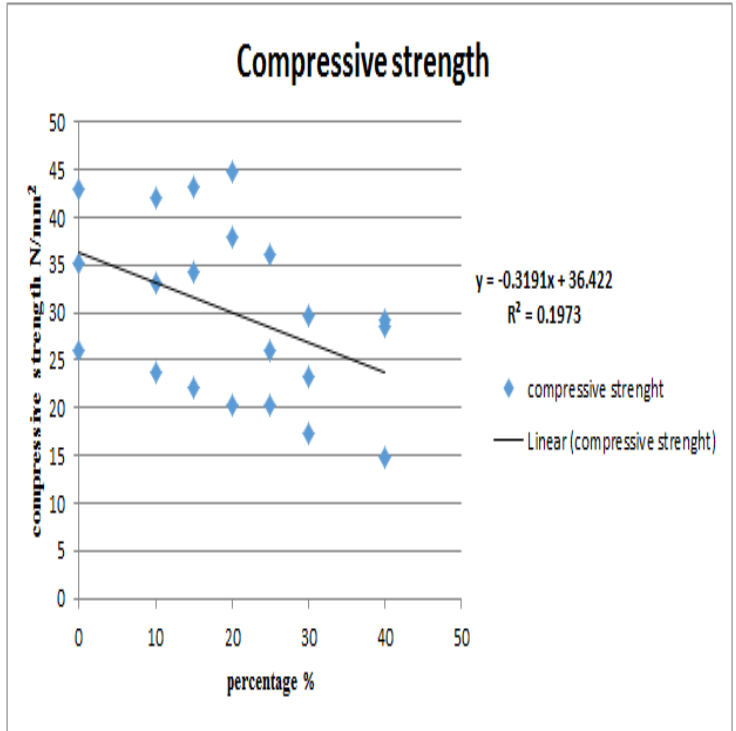

Figure 6: Compressive Strength of Concrete for various percentages of mineral admixtures

\subsection{Flexure Strength :}

Concrete as we know is respectively strong in compression and weak in tension.

Flexure strength $(f b)=\frac{P L}{b^{2}}$

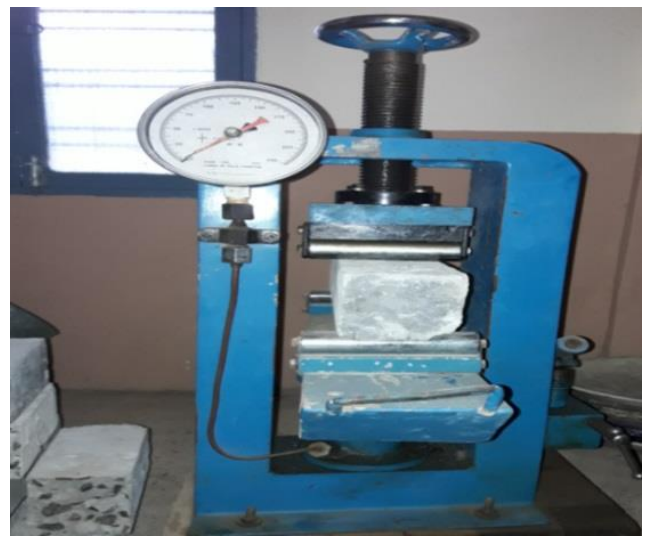

Figure 7 Flexural strength testing machine

Table 7 Flexural Strength Test Results

\begin{tabular}{|c|c|c|c|}
\hline \multirow{2}{*}{ Percentage \% } & \multicolumn{3}{|c|}{ Flexural Strength $\left(\mathbf{N} / \mathbf{M m}^{2}\right)$} \\
\cline { 2 - 4 } & 7 Days & 28 Days & 50 Days \\
\hline 0 & 3.2 & 5.5 & 7.29 \\
\hline 10 & 5.13 & 13.8 & 20.2 \\
\hline 15 & 3.77 & 17 & 20 \\
\hline 20 & 6.6125 & 18.4 & 23.78 \\
\hline 25 & 5 & 13 & 20.2 \\
\hline 30 & 5.2 & 12.7 & 20.6 \\
\hline 40 & 3.5 & 14 & 18.91 \\
\hline
\end{tabular}

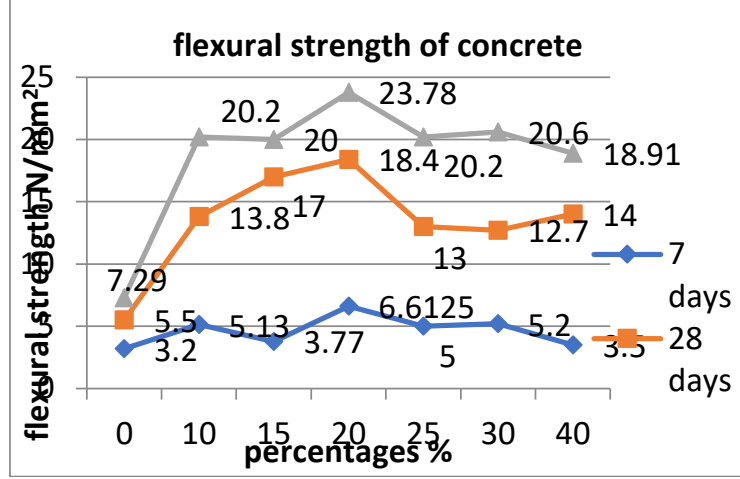

Figure 8: Flexural Strength of Concrete percentages of mineral admixtures

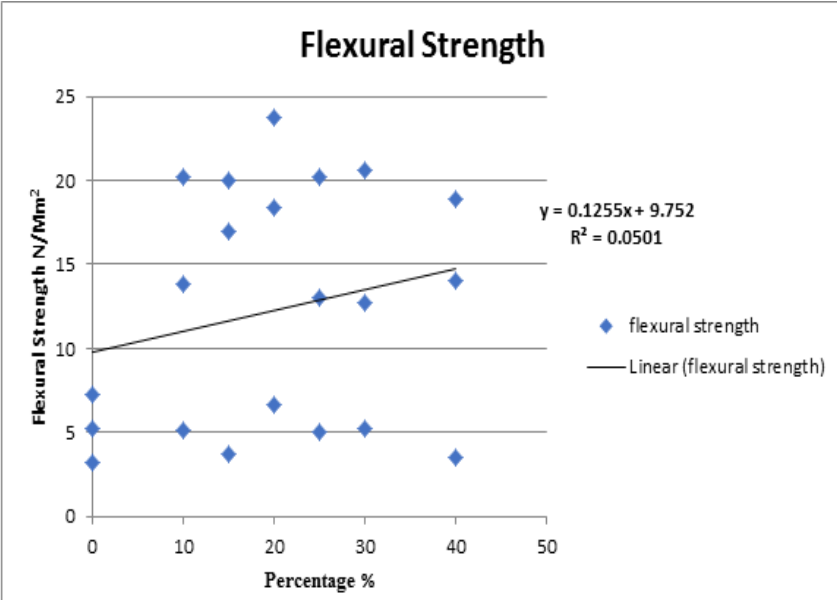

Figure 9: Flexural Strength of Concrete for various percentages of mineral admixtures

\subsection{Split Tensile Strength:}

The main advantage of this method is that the same type of specimen and the same testing machine as are used for the compression test can be employed for this test. Strength determined in the splitting test is believed to be closer to the true tensile strength of concrete, than the modulus of rupture. Splitting strength gives about 5 to $12 \%$ higher value than the direct tensile strength.

Split tensile strength $(\mathbf{f s})=\frac{2 P}{\pi L D}$

\section{Where,}

$\mathrm{P}=$ Maximum Load on Cylinder in $\mathrm{KN}$

$\mathrm{L}=$ Length of the Cylinder in $\mathrm{mm}$

$\mathrm{D}=$ Diameter of the Cylinder in $\mathrm{mm}$

Table 8 Split Tensile Strength Test Results

\begin{tabular}{|c|c|c|c|}
\hline \multirow{2}{*}{ Percentage \% } & \multicolumn{3}{|c|}{ Split Tensile Strength $\left(\mathbf{N} / \mathbf{M m}^{\mathbf{2}}\right)$} \\
\cline { 2 - 4 } & 7 Days & 28 Days & 50 Days \\
\hline 0 & 2.4 & 3.4 & 4.3 \\
\hline 10 & 2.3 & 3.56 & 4.8 \\
\hline 15 & 2.1 & 3.2 & 4.2 \\
\hline 20 & 2.22 & 3.4 & 6.08 \\
\hline 25 & 2.1 & 3.4 & 4.2 \\
\hline 30 & 0.884 & 2.33 & 3.849 \\
\hline 40 & 0.561 & 2.132 & 3.77 \\
\hline
\end{tabular}




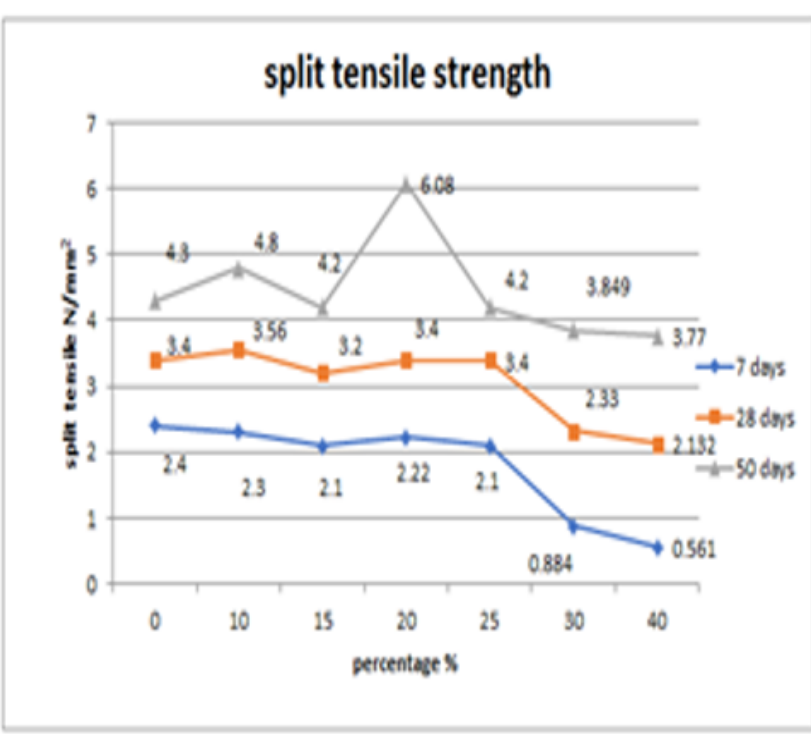

Figure 10 Split tensile strength of concrete

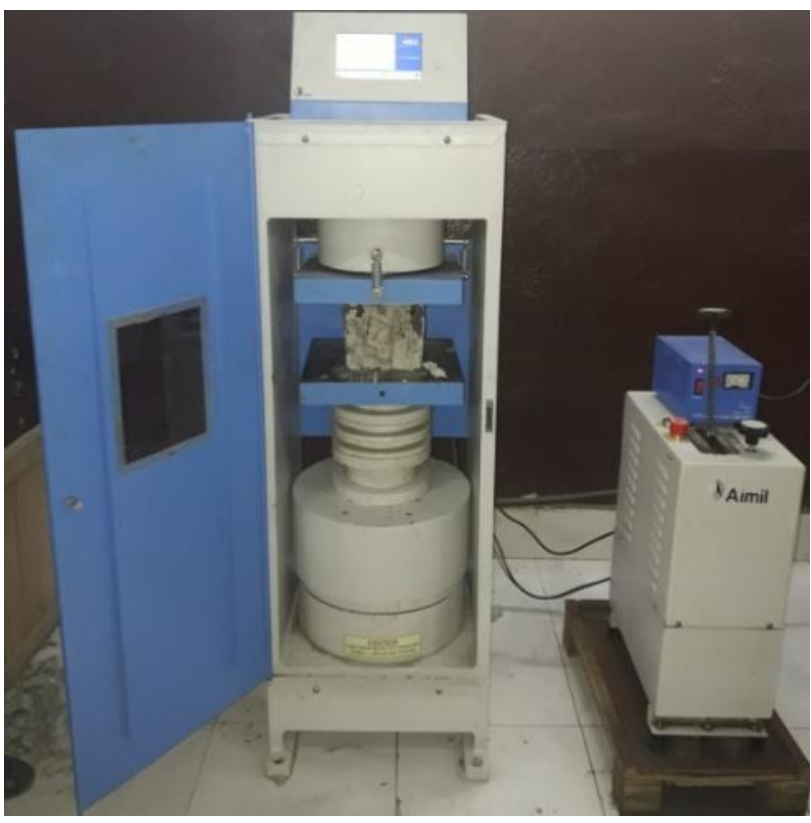

Figure 11 Split Tensile Testing Machine

\subsection{Discussions}

The following discussions are discussed according to results and bar charts.

\subsubsection{According to Figure 1.10 :}

Compressive strength of cube at the rate of 7, 28,50 days at different percentages of fly ash and GGBS $0 \%, 10 \%, 20 \%, 30 \%$ \& $40 \%$.

\section{Trail mix}

1. The compressive strength of cube at the rate of trail mix is increased by $35.38 \%$ when compare with 7 days strength at 28 days strength.

2. The compressive strength of cube at the rate of

3. Trail mix is increased by $22.15 \%$ when compare with 28 days strength at 50 days strength.

4. The specimens immersed in water did not show any visible sign deterioration after the 28 days immersion period but rather show continuous improvement in compression strength.

\section{$5 \%$ fly ash \& $5 \%$ GGBS}

1. The compressive strength of cube at the rate of $5 \%$ fly ash and 5\% GGBS is increased by $40.08 \%$ when compare with 7 days strength at 28 days strength.

2. The compressive strength of cube at the rate of $5 \%$ fly ash and 5\% GGBS is increased by $26.50 \%$ when compare with 28 days strength at 50 days strength.

3. The compressive strength of concrete generally increases with age but decreases with increase in replacement level of cement by fly ash and GGBS.

$10 \%$ fly ash \& $10 \%$ GGBS

1. The compressive strength of cube at the rate of $10 \%$ fly ash and 10\% GGBS is increased by $87.19 \%$ when compare with 7 days strength at 28 days strength.

2. The compressive strength of cube at the rate of $10 \%$ fly ash and 10\% GGBS is increased by $17.89 \%$ when compare with 28 days strength at 50 days strength.

\subsubsection{According to Figure 1.16:}

Split tensile strength of cylinders at the rate of 7,28\& 50days with different percentages of fly ash and GGBS $0 \%, 10 \%, 20 \%, 30 \%$, $\& 40 \%$

\section{Trail Mix:}

1. The split tensile strength of cylinders at the rate of $0 \%$ fly ash and 0\% GGBS is increased by $41.6 \%$ when compare with 7 days strength at 28 days strength.

2. The split tensile strength of cylinders at the rate of $0 \%$ fly ash and 0\% GGBS is increased by $26.47 \%$ when compare with 28 days strength at 50 days strength.

\section{5\% flyash\& 5\%GGBS:}

1. The split tensile strength of cylinders at the rate of $5 \%$ fly ash and 5\% GGBS is increased by $54.78 \%$ when compared with 7 days strength at 28 days strength.

2. The split tensile strength of cylinders at the rate of $5 \%$ fly ash and 5\% GGBS is increased by $34.83 \%$ when compared with 28 days strength at 50 days strength.

\section{$10 \%$ fly ash \& $10 \%$ GGBS:}

1. The split tensile strength of cylinders at the rate of $10 \%$ fly ash and $10 \%$ GGBS is increased by $53.15 \%$ when compared with 7 days strength at 28 days strength.

2. The split tensile strength of cylinders at the rate of $10 \%$ fly ash and $10 \%$ GGBS is increased by $78.82 \%$ when compared with 28 days strength at 50 days strength.

\subsubsection{According to Figure 1.13 :}

Flexural strength of beams at the rate of 7,28 \& 50 days with different percentages of fly ash and GGBS $0 \%, 10 \%, 20 \%, 30 \%, \& 40 \%$.

\section{Trail mix:}

1. The flexural strength of beams at the rate of $0 \%$ fly ash and $0 \%$ GGBS is increased by $71.87 \%$ when compare with 7 days strength at 28 days strength.

2. The flexural strength of beams at the rate of $0 \%$ fly ash and $0 \%$ GGBS is increased by $32.54 \%$ when compare with 28 days strength at 50 days strength.

\section{$5 \%$ fly ash and $5 \%$ GGBS:}

1. The flexural strength of beams at the rate of $5 \%$ fly ash and 5\% GGBS is increased by $16.9 \%$ when compare with 7 days strength at 28 days strength. 
2. The flexural strength of beams at the rate of $5 \%$ fly ash and $5 \%$ GGBS is increased by $46.37 \%$ when compare with 28 days strength at 50 days strength.

\section{$10 \%$ fly ash and $10 \%$ GGBS:}

1. The flexural strength of beams at the rate of $10 \%$ fly ash and $10 \%$ GGBS is increased by $17.8 \%$ when compare with 7 days strength at 28 days strength.

2. The flexural strength of beams at the rate of $10 \%$ fly ash and $10 \%$ GGBS is increased by $29.2 \%$ when compare with 28 days strength at 50 days strength.

\subsubsection{According to Figure 1.11}

The ultimate compressive strength attained at $20 \%$ replacement, beyond that the compressive strength will be decreased so the regression value attained at $20 \%$ replacement and the value is in between the limits.

\subsubsection{According to Figure 1.14}

The ultimate flexural strength attained at $20 \%$ replacement, beyond that the flexural strength will be decreased so the regression value attained at $20 \%$ replacement and the value is in between the limits.

\subsubsection{According to Figure 1.17}

The ultimate split tensile strength attained at $20 \%$ replacement, beyond that the split tensile strength will be decreased so the regression value attained at $20 \%$ replacement and the value is in between the limits.

\section{Conclusions:}

Based on experimental analysis report the following conclusions can be given.

1. It is observed that GGBS and Fly ash based concrete strength has been increase for $20 \%$ replacement of cement at the age of 7 days, 28 days and 50 days.

2. From the experimental results, it is presuming that GGBS and Fly ash can be used as replacement material for cement, to deduct the cost of construction.

3. It is also noted that the flexural strength increase gradually with increase in composition of GGBS and Fly ash up to $20 \%$ replacement.

4. Split tensile strength also increase gradually with increase in composition of GGBS and Fly ash up to $20 \%$ replacement.

5. There are no major deviations in spilt tensile strength at the age of 7 days and 28 days up to $20 \%$ replacement.

6. The workability of concrete was reduced when compared to the normal concrete because of addition of mineral admixtures such as GGBS and Fly ash.

7. As per regression analysis the regression curve fitted up to $20 \%$ replacement so the mineral admixtures were added up to $20 \%$ is acceptable.

\section{Future Scope of Work}

1. To study the durability properties of concrete with partial replacement of various mineral admixture dosages.

2. To study the mechanical properties of concrete with accelerated curing.

3. One of the technic to develop the green concrete in reducing the pollution.

4. To study the NDT on concrete with partially replaced mineral admixtures.

\section{References}

[1] S.Arivalagan.,(2014), " Sustainable Studies on Concrete with GGBS As a Replacement Material in Cement." Jordan Journal of Civil Engineering, Volume 8, No. 3, 2014.

[2] HimabindhuMyadaraboina, "Development of high volume fly ash concrete using ultrafine fly ash", 23rd Australasian Conference on the Mechanics of structures and Materials (ACMSM23), Byron Bay, Australia, 9-12 December 2014, S.T.Smith (Ed.)

[3] T.Renganathan, A.R.Akiladevi, R.DebyLinsha, Y.PreethyDharanya, "Comparative Study on Strength Properties of Concrete with Different Cementitious Materials" International Journal of Engineering Trends and Technology (IJETT) - Volume42 Number-1 - December 2016.

[4] Shankar Mishra,Pankaj Kumar Choudhary, Pawan Taneja, Naman Gupta, ManojOlla,KamleshSaini, "Studies on Utilisation of GGBS and Fly Ash to MakeGreen Concrete", SSRG International Journal of Civil Engineering (SSRG-IJCE) - volume 3 Issue 5 - May 2016.

[5] R. B.Sheral, D. Sutar\& P. Jagdane, "Utilization of Waste Materials (GGBS+FLY ASH)", International Journal of Latest Technology in Engineering, Management \& Applied Science (IJLTEMAS)Volume V, Issue VII, July 2016.

[6] P. Vipul Naiduand Pawan Kumar Pandey, "Replacement of Cement in Concrete", International Journal of Environmental Research and Development. ISSN 2249-3131 Volume 4, Number 1 (2014), pp. 91-98.

[7] A.Palaniappan,S.Vasantha,S.SivaPrakasan,S.Prabhu $\quad(2 \quad 013)$ "GGBS as Alternative to OPC in Concrete as an Environment Pollution Reduction Approach" International Journal of Engineering Research and Technology (IJERT)Volume 2 Issue 6.

[8] Mohammed nadeem, arun D. Pofale, "Experimental investigation of using slag as an alternative to normal Aggregates (coarse and fine) in concrete", International journal of civil and structural engineering, Volume 3, 2012

[9] Mrs. Veena G. Pathan, et al, "Evaluation of concrete properties using ground granulated blast Furnace slag", International Journal of Innovative Research in Science, Engineering and Technology Vol. 1, Issue 1, (2012), pp7179.

[10] Roy, D. M., Luke, K., and Diamond, S., (1984), “Characterization of Fly Ash and its Reactions in Concrete, "Materials Research Society Symposium Proceedings, Boston, Vol. 43, 3-20.

[11] Babu G.K. and Rao S.N.G., Efficiency of fly ash in concrete, Cement and Concrete Composites, 1993, Vol. 15, pp. 223-229

[12] Ganesh Babu K and Sree Rama Kumar V, 'Efficiency of GGBS in concrete', Cement Concrete Research, Vol. 30, 2000; pp.10311036.

[13] IS: 456-2000, Indian standard Specification for plain and reinforced concrete - code of practice. (Fourth revision), B.I.S., New Delhi.IS: 9103-1999, "Specification for Concrete Admixtures" Bureauof Indian Standards, New Delhi, India

[14] IS: 516-1959, Indian Standard Methods of Test for Strength of concrete. Bureau of Indian Standards, New Delhi.

[15] Munday J.G.L. Ong L.T. and Dhir R.K., Mix proportioning of concrete with PFA: critical review. Fly ash, silica fume, slagand other mineral by-products in concrete, SP-79, ACI, 1983,Vol. 1, pp. 267-288.

[16] Bharatkumar B.H. Narayanan R. Raghuprasad B.K. and RamachandramurthyD.S., Mix proportioning of high performance concrete, Cement and Concrete Composites, 2001, Vol. 23, pp. 71 80

[17] Dr S.L. Patil, J.N. Kale, S Suman (2012), “ Fly ash concrete: Atechnical analysis for compressive strength", International Journal Of Advanced Engineering Research and Studies, Volume II, Issue I, pp 128-129.

[18] Effect of Partial Replacement of Cement by Ground-Granulated Blast-Furnace Slag and Fine Aggregate by Marble Slurry on Properties of Concrete Er. Arvind Singh Gaur 1 ,Er. Sachin Kumar2 1 (Civil engineering, SR Group of Institution Jhansi / Dr. APJ Abdul Kalam technical university, Lucknow, India).

[19] Experimental investigation on strength of concrete by partial replacement of cement using Fly Ash \& GGBS at elevated temperature 
[20] Effect of Partial Replacement of Cement by Ground-Granulated Blast-Furnace Slag and Fine Aggregate by Marble Slurry on Properties of Concrete Er. Arvind Singh Gaur 1 ,Er. Sachin Kumar2 1 (Civil engineering, SR Group of Institution Jhansi / Dr. APJ Abdul Kalam technical university, Lucknow, India).

[21] IS: 10262-2009,“ Guidelines for Concrete Mix Design”,Bureau of Indian Standards, New Delhi, India.

[22] Malhotra V.M. and Mehta P.K., Pozzolanic and cementitiousmaterials, Advanced Concrete Technology, 1, Gordon and Breach Publishers, Canada, 1996. 